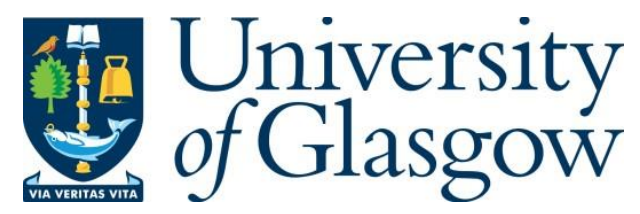

Theodoropoulos, P. (2018) Barriers to migrant worker unionization: examining the impact of structural and subjective barriers to migrant worker unionization in the UK. Journal of Labor and Society, 21(3), pp. 317-335.

There may be differences between this version and the published version. You are advised to consult the publisher's version if you wish to cite from it.

This is the peer reviewed version of the following article Theodoropoulos, $\mathrm{P}$. (2018) Barriers to migrant worker unionization: examining the impact of structural and subjective barriers to migrant worker unionization in the UK. Journal of Labor and Society, 21(3), pp. 317-335, which has been published in final form at http://dx.doi.org/10.1111/wusa.12346. This article may be used for non-commercial purposes in accordance with Wiley Terms and Conditions for Self-Archiving.

http://eprints.gla.ac.uk/168474/

Deposited on: 12 December 2018

Enlighten - Research publications by members of the University of Glasgow http://eprints.gla.ac.uk 


\title{
Barriers to Migrant Worker Unionization: Examining the impact of structural and subjective barriers to migrant worker unionization in the UK
}

\begin{abstract}
Despite being disproportionately concentrated in the most precarious jobs of the UK labour market, migrant workers are disproportionately absent from unions. This study aims to examine the structural and subjective impediments to migrant worker unionisation. To address subjectivities but also to counter the exclusion of migrant voices from the relevant literature, a qualitative approach employing interviews and an auto-ethnography was chosen. It is argued that, alongside a variety of subjective and structural factors, the almost total absence of trade unions from many migrants' lives is a significant contributor to their lack of participation. The study concludes with some recommendations towards improving union outreach to migrant communities, arguing that a substantial part of trade unions' 'traditional', hierarchical, class-centred remit must be overturned and replaced by intersectional and non-hierarchical organising methods in order for them to be able to organise, work with, and empower migrant workers.
\end{abstract}




\section{Section 1: A Brief Introduction to the Conditions of Migrant Labour}

Entering a society already characterised by the proliferation of precarity to all spheres of social life (Casas-Cortés 2014; Federici 2012; Jørgensen 2016; Standing 2011), migrant workers in the UK are overwhelmingly concentrated in the most precarious, exploitative, and symbolically stigmatised jobs of the market (indicatively, see Anderson and Ruhs 2010; Miles 1982). Overwhelmingly over-educated for the jobs that they perform (Office for National Statistics 2017), they are routinely subject to pressure, instability, and the constant, overhanging threat of dismissal (Meardi et al 2012; McKay and Markova 2010). The distribution of migrants within an already constrained labour market is heavily gendered and further structured by essentialist stereotypes that attribute certain characteristics to specific migrant groups (McDowell 2008). The conditions described above are structured by and themselves participate in structuring an increasingly dangerous wave of xenophobia which is antagonistic to migrant workers and fractures possibilities of developing solidarities along class lines (Yilmaz 2012). As Young (1990) points out, cultural perceptions of non-economic categories such as ethnicity, race, gender and sexuality have direct economic effects, directly structuring society and conditioning actors' interactions so deeply that they are essentially inseparable from coherent economic analyses. This study is concerned precisely with investigating the interaction of these categories and how they combine to influence migrant worker unionisation processes.

Due to a combination of factors characteristic of the experience of these migrant groups such as de-skilling, legal status, lack of familiarity with the new labour market they find themselves in, an initial sense of temporariness and disconnection from the social setting they find themselves in, the language barrier, and their preference for quick jobs that have less strict selection criteria, migrants provide a supply of easily-exploitable labour (Anderson and Ruhs 2010; Holgate 2005; Piore 1979). Operating in a tight and competitive market, UK employers have a constant requirement for this sort of precarious, flexible and obedient labour (Anderson 2013; Holgate 2005). This is especially relevant in sectors that are defined by intense working conditions, anti-social hours, high turnover rates and social stigmatisation (Menz and Caviedes 2010). Recruitment agencies are ideally placed to provide this type of labour and play a fundamental role in the introduction of migrants to the UK market and on their subsequent management and distribution (McCollum and Findlay 2015; McKay and Markova 2010; Sporton 2013). Upon interviewing agency recruiters, McCollum and Findlay (2015: 439) conclude that labour markets and migrant labour are connected by a mutually reinforcing relationship where 'flexible labour markets create a structural demand for migrant labour and a ready supply of migrant labour allows flexible labour markets to flourish'.

Migrant unionization has to be examined in conjunction with the wider decline of union power and influence in the UK. According to the UK's Department for Business, Energy and Industrial Strategy (2017), 'around 6.2 million employees in the UK were trade union members in 2016. The level of overall union members decreased by 275,000 over the year from 2015 (a 4.2\% decrease), the largest annual fall recorded since the series began in 1995. Current membership levels are well below the peak of over 13 million in 1979'. Temporary postings make it difficult to build up the relationships, trust, and strategy required to organise (Bauman 2004; Woodcock 2014); contractual insecurity regularly handicaps resistance through fear of being harshly penalised (Moore 2011); and the anxiety and outright exhaustion resulting from harsh working conditions (Anderson 2010) leave little space for such thoughts. These issues are amplified in the context of temporary work: in 2016, $24.2 \%$ of permanent employees were members of trade unions as compared to only $13 \%$ of 'temps' (Department for Business, Energy and Industrial Strategy 2017). The combination of these factors together with a non-confrontational and class-collaborationist mentality from the dominant unions (Keenan 2015) has resulted in the concentration of union activity chiefly in the relatively secure public sector, which in 2014 had a $56.7 \%$ union density as compared to the private sector's $14.2 \%$ (Tapia 2014: 55). 
At this point, a distinction is necessary: migration is varied and multi-faceted, and migrants are not simply automatically inserted into the worst jobs of the 'secondary labour market' simply to meet the demands of economic competition, as Piore (1979) wrote in his famous study of migrant labour. Indeed, migrants represent $12 \%$ of those employed in the financial and business sectors (Office for National Statistics 2017), hardly a 'secondary labour market'. This study is not concerned with those migrants. It is a primarily political attempt to highlight barriers to unionization experienced by migrants facing conditions of precarity in the UK, and its ultimate aim is to contribute to the overcoming of these barriers. While these migrant workers are further stratified and differentiated in terms of race, ethnicity, gender, legal status, and other categories, there are, as will be shown, some key commonalities in their socio-political exclusion which should directly concern unions and social movements.

\section{Section 2: Migrant Unionisation and Agency}

Despite their precarious condition, migrant workers remain overwhelmingly un-unionized, with a membership rate of only $16.2 \%$ as compared to the $25 \%$ of the UK-born (Department for Business, Energy and Industrial Strategy 2017). Even though a plethora of literature has been published on existing migrant labour campaigns (examples include Adler et al 2014; Holgate 2005; Jayaraman and Ness 2005; Lagnado 2015; Lopez and Hall 2015; Però 2014), there are comparatively few that examine why these campaigns have not proven generalizable. In the existing literature, predominant explanations for the gap between the unionization rate of locals and migrants can be generally split into two strands: those focusing on the migrant condition and those focusing on union activity.

Explanations grounded on the immigrant condition as a factor preventing the mobilization of immigrant workers tend to draw un-empirical conclusions based upon their authors' calculations of the subjectivities produced through the migrant experience. Nevertheless, some of these are wellfounded, emanating from an analysis of the structural characteristics of the labour markets in which most migrants are employed; for example, Kranendonk and de Beer (2016) locate explanations in the language and cultural differences of migrants, the generally low union density of the private sector and, crucially, in the perceptions of unions that migrants bring with them from their countries of origin. Similarly, Moore (2011) finds that many workers from Eastern Europe are reluctant to join unions because of their negative associations with the repressive historical communist regimes of their countries. This understanding resonates with Sayad's (2004) assertion that immigrants are also emigrants- they transport their socialisation from their home countries to their new setting. Marino et al (2015) further argue that, other than labour market position, legal status also plays a role in debilitating migrant mobilization, as non-EU migrants who are dependent on a Visa tying them to a specific employer may be reluctant to risk getting fired for union activity. Moore (2011) touches upon all these aforementioned points and highlights the importance of the already precarious context inside which migrants arrive.

This method however entails the danger of leading to crude trivialisations of the complexities surrounding migrant worker unionisation. For example, Piore (1979: 109-110) writes that 'temporary migrants do not have a long-term interest in the community, and this is bound to affect their interest in political participation. As a general rule, they simply do not see themselves as being around long enough to make most issues of community development and structure relevant'; however, no justification is provided for this conclusion- it is something that is assumed to logically follow from migrants' experiences of temporariness, the 'dual frame of reference', and the economistic rationality mentioned above. Migrants are portrayed as selfish automata without a history or a sense of dignity. While the above approach is helpful in examining a subjectivity that really is caught between two worlds, it is problematic insofar as it contributes to a reduction of the complexity of a migrant's agency 
to a simple comparative calculation. An accurate generalisation covering such a heterogeneous group is impossible to make (Alberti et al 2014); however, departing from an understanding of how migrant labour is structured, it is possible to conclude that migrants do not simply 'accept' bad working conditions because they are 'better' than the ones they left; rather, migrants are positioned in specific occupations and conditions by a wide interplay of structural and cultural forces (Anderson 2013). This line of critical reasoning also applies to migrant labour mobilization- as will be illustrated, the reasons for the relative lack thereof are more complex than can be covered by one-dimensional explanations.

Union-oriented explanations centre on how union activity encourages or discourages migrant participation. A significant question this body of literature attempts to answer is whether to include migrants as general members of the working class or to set up special structures within the union which would cater to immigrant-specific concerns (Tapia 2014). For example, Connoly et al (2014) propose that union strategy towards migrant workers is based on three different logics: those of class (focusing on the commonalities of the class position of migrants and locals), race or ethnicity (focusing on empowering minority workers), and social rights (targeting wider issues of concern to migrant workers such as housing or status). They conclude that these three logics exist in tension and that one point of the triangle is found lacking in most union strategies: in the case of the UK, they find that unions focus on class and race and ethnicity but generally neglect the logic of social rights.

Alternatively, Martínez Lucio and Perret (2009) trace three predominant union strategies for engagement of migrant workers. The bargaining strategy concerns collective bargaining over important labour issues, yet the authors find that specific concerns of migrants such as 'extended leave for religious purposes or religious holidays, remain undeveloped' (2009: 334). The second strategy is to incorporate migrants by providing educational services, for example through the Union Learning Fund; according to the authors, this strategy's limitations are that it does not cater to the needs of more established migrant communities and that it employs hierarchical, messianic politics which are 'obsessed with bureaucratically ensuring a controlled, regulated community' (2009: 335-7). The final strategy involves the mobilization of the leaders, which once again displaces the participation of the wider community and is focused more towards the creation of union-loyal cadres rather than substantial empowerment (2009: 337-9).

Upon interviewing British trade union officers, Wrench (2004) finds that some unions have departed from the universalistic position of treating migrants simply as members of the working class and have attempted to ensure representational proportionality; however, he deems that substantive representation demands the implementation of positive discrimination practices, a development which he doubts will happen. Analysing the participation of Black members in trade unions, Virdee and Grint (1994) write that formal proclamations of anti-racism and inclusion often mean practically little; empowerment arises not through the white majority's attempts at inclusion but rather through semi-autonomous minority-led structures established within the wider institutional structure. Further enforcing the claim that migrant autonomy is essential for the organisation of migrant workers, Marino (2015) claims that the unions with less hierarchical, more democratic organisation that encourage and facilitate the rank-and-file to be active in daily union activities are more successful in engaging migrants. On a practical note, Martínez Lucio and Perret (2009: 706) point to how the methods unions employ for outreach ('leaflets, meetings, officer led initiatives') may not be the best for reaching migrant communities with specific demands and conditions (for example, a meeting is hard to attend for someone working anti-social hours or who is not comfortable with English).

The same strand includes a variety of studies that have focused on the potential afforded by the mobilization of intersectional analyses in furthering migrant unionization. Thus Alberti et al (2014) find that the most effective campaigns engaged with migrant workers as migrant workers, conscious of their specific intersectional positionalities and cognizant of particular needs of each group. The above studies therefore suggest that a key reason for the limited participation of migrants in union activity is precisely unions' tendency to engage with migrants simply as members of the working class 
through a reductive, economistic lens (Alberti et al 2013; Jayaraman and Ness 2005). Significantly, a common concern in the literature relates to the exclusionary and discriminatory attitude of some unions who actively choose to ignore migrant workers until they are perceived as 'settled' or come to 'dominate certain sectors of the labour market' (Piper 2010: 109). Finally, in an illuminating analysis that could be applied to the British context, Cappiali (2017) provides interviews with migrant workers in Italy that claim they are being manipulated and tokenised by the major organisations of the Italian left, including trade unions.

While focusing on the sphere of union activity is effective in remedying the reductive propensity to attribute migrants' lack of political mobilization to their conditions of existence, nevertheless a tendency exists to focus on top-down union strategies while ignoring the agency of migrant groups. This is most strikingly demonstrated in Gorodzeisky and Richards (2013) where they argue that an important factor in unions' approaching of migrant groups is their organisational security (the extent to which it is easy for them to exist and reproduce themselves through recruitment). They claim that union strategy is premised on membership considerations and that weaker unions will tend to approach migrants to increase their membership. This explanation is inadequate because it completely overlooks the agency of immigrant workers. Indeed, unions such as the Latin American Workers' Association were organised autonomously by migrant workers, thereby refuting this position (Lagnado 2015). Furthermore, Gorodzeiksy and Richards (2013) mistakenly assume that the main concern of unions is self-reproduction rather than class solidarity. Again, this position cannot be generalized to apply to all unions present in the UK.

The above article is the most illustrative manifestation of a general trend observed in varying degrees in the literature, whereby migrants are viewed as mere receptacles of charity or acceptance rather than as active subjects. In a manner reminiscent of Spivak's (1988) analysis that subaltern groups are denied the very means of articulating their demands and positions, many of the aforementioned studies exhibit a troubling lack of inclusion of migrant voices. While Però and Solomos (2010) correctly write that there has been an increasing interest in that regard, the only studies in the literature covered that interviewed migrants were those focused on campaigns of already mobilized migrants (such as Alberti 2014; Holgate 2005; Lopez and Hall 2015; Però 2014) or those examining other aspects of the migrant experience (such as Mackenzie and Forde 2009; Sporton 2013). Paradoxically, works such as those of Wrench (2004), Connoly et al (2015), Martínez Lucio and Perret (2009), Gorodzeisky and Richards (2013), Piper (2010) and Kranendonk and de Beer (2016), concerned precisely with the issue of migrant unionism, have not foregrounded migrant voices. This parallels a migrant worker's exasperated proclamation that 'there is no real platform where we can compete in the political arena as equals and make our own legitimate claims as individuals and as collective political forces. They always talk about us, but never truly with us!' (Cappiali 2017: 976). According to Freire (1993 [1970]: 115), a fundamental feature of oppression is that the oppressed have had their words, their very means of articulating their reality, 'stolen from them'. A prerequisite, therefore, for meaningful political activity is the reclamation of the right to and the means of speech (Freire 1993 [1970]), something which migrant workers are generally denied even in supportive academic literature.

The silencing of migrant voices is undoubtedly problematic for any contribution aiming to assist the migrant worker struggle; however, attempts to rectify this by locating examples of agency where they don't exist are equally problematic and tend to ignore the underlying forces structuring migrant worker oppression. For example, Parutis (2014) describes a strategic utilisation of precarity where migrants' trajectories are seen in progressive stages, ultimately leading to the 'dream job' stage. While these subjective experiences may be true, they constitute attempts to negotiate an objectively oppressive and unequal positionality- whether viewed positively in relation to a worst situation or not, their experiences remain structured by institutionalised prejudice and precarity. Moreover, the reality of progression to a 'dream job' remains an inaccessible fantasy for most (Sporton 2013, Recchi and Triandafyllidou 2010). A further example of this tendency can be located in Alberti's (2014) work on 
the uses of mobility by migrant workers: the author claims that, since capital intrinsically relies on the provision of labour by workers, a key aspect of migrants' agency in resistance is the utilization of their precarity to quit their job 'when it became unbearable or no longer useful to sustain their life or occupational projects' (2014: 875). In a highly relevant article criticizing subaltern theorists' analysis of agency, Mujamdar (2017) argues that 'choosing between two options that have been generated by an oppressive social structure is not resistance - it is acquiescence to that order'. In the case of the migrant workers studied by Alberti (2014), 'that order' is one of an economic landscape characterised by precarious labour alongside particular social forces that make migrants more prone to be located precisely in those occupations; given this context, whether migrant workers choose to stay in such a job or utilize their precarity in order to go to another precarious job is irrelevant to significant emancipatory social change.

As Young (1990) argues, issues of class, created and perpetuated by the capitalist foundations underpinning society, permeate all other social positionalities; class and the increasingly hostile economic environment is a significant structural force in the oppression of migrant workers. This is why trade-union activity, enhanced by intersectional analysis yet without eschewing the importance of class-based resistance, remains an indispensable component of migrant resistance (Moore 2011; Però 2014). Moreover, owing to the intersection migrant workers occupy between the domains of class, race, ethnicity, and gender and due to their close relation to influential processes such as precarity, globalisation and xenophobia, they are uniquely placed to contribute to the radical struggle against modern inequality (Jørgensen 2016).

\section{Section 3: Methodology}

A critical epistemological approach was employed that aimed not only at exposing and addressing injustice on the ground (Holgate 2005), but also in the purportedly 'supportive' academic sphere. This research follows Osterweil and Chesters (2007) in attempting to unite theory, action and narrative and rejecting epistemologies detached from the social context they investigate. I am an active trade-unionist and a migrant worker; I am therefore inextricably tied to the topic of research. In a direct attempt to address the exclusion of migrant voices in the relevant literature, a qualitative methodology was chosen consisting of nine semi-structured interviews (ranging from 20 to 90 minutes) and a covert auto-ethnography of a workplace employing migrant workers in conditions of precarity. The cover methodology was chosen to enable me to fully participate, experience and observe the reality of the chosen workplace without being fired by the management (who, as will be made evident below, would not be happy if they knew someone was researching their labour practices). The university under which I conducted this research did not grant me ethical approval to interview my co-workers in the location of the auto-ethnography. The interviews are therefore entirely separate from the location and people involved in the auto-ethnography. Nevertheless, the co-workers I trusted were aware of my trade-union background as well as my research activity.

Predominantly European Union migrants were selected for interviews in order to control for the 'common-sense' position that immigration status, tying people to a certain employer through a $V i s a$, is a fundamental factor curtailing migrant unionisation. Since EU migrants don't suffer from this limitation and yet remain under-represented in unions, it seemed to me that reasons other than status are significant. This decision was enhanced by the fact that EU migrant workers are usually white with relatively high levels of education and are (relatively) culturally proximate to the British, indicating that race, qualifications and culture are also not enough to explain the unionization disparity by themselves. However, two non- EU migrant workers were also interviewed to investigate the added complexities of status, race and culture. Furthermore, while gender emerged from the literature as a significant structuring force in migrant workers' experience, none of the studies analysing migrant worker unionization significantly touched upon its role. To include the impact of gender, five 
interviews with female migrant workers were conducted. Furthermore, the exclusion of trade-union officials from the interviews was deliberate. Many unions have formal structures set up that address migrant or BME communities, and I would have surely been pointed towards them; on the contrary, my aim was to examine whether or not the presence of these structures had been actually felt by the migrant workers themselves.

The auto-ethnography provided me the opportunity to corroborate and enhance the information gathered from the interviews and the literature and to more deeply analyse the migrant labour market through reflection on my own experience. The tactics management employs at pacifying and dividing the workforce, for example, were not significantly touched upon in the interviews but were directly experienced in the auto-ethnographic process. During my month working as a kitchen porter in a precarious and largely immigrant-staffed restaurant, I focused on the following topics: (1) how precarity structures labour experience; (2) the impact of precarious labour relations on the potential for unionization; (3) the interactions between workers and management; and (4) the perceptions migrant workers have of unions and unionization. The addition of the auto-ethnography thereby completes a robust research structure that draws on diverse sources of information to craft a consistent analysis of the structural and subjective impediments to migrant worker unionization.

Nevertheless, this study has important limitations. Four of the interviewees were accessed through my own trade union, the Industrial Workers of the World; while this provided the opportunity to gather information from politically conscious activists that can connect their experiences to wider social structures, it also curtailed the appearance of spontaneous, experiential disclosures. There is therefore a danger of confirmation bias. Overall, the interviewees exhibited a high degree of political awareness, were overwhelmingly educated at a university level, and were disproportionately of a Spanish background (four out of nine). No interviews were conducted with Eastern European workers which represent a significant portion of migrant workers concentrated in precarious occupations; having no personal Eastern- European contacts, I had hoped to gain access to this demographic through my job. This was not the case. Furthermore, no black, refugee, or asylum-seeker participants were accessed; while the research tactically focuses on white EU migrants, their total lack of voice represents an academic and political failure. This gap was partially addressed by engaging with literature that specifically analyses the position of racialised workers in the UK market, such as Miles (1982), Wrench and Solomos (1993) and Virdee and Grint (1994) and will be further pursued in future research.

The most significant and glaring limitation is the small number of interviews conducted and the limited time-frame in which the ethnography took place. At this point, it is also important to state that, despite the short duration, the specific conditions I encountered completely resonate with my wider experiences as a precarious migrant worker in the UK over the course of six years. The limitations notwithstanding, this publication had the political and intellectual aim of foregrounding migrant worker voices and experiences in the analysis of this social group's unionization, something which is currently rare. Additional research is necessary that covers the experiences of more migrant groups (especially more that are not from the EU) and in a wider range of sectors. I am currently conducting wider research to produce more representative results. It is hoped that this contribution is a step in the direction of rectifying the lack of migrant voices from literature that concerns us; therefore, this study should be looked at as belonging to the start (which a variety of other theorists and activists have initiated), rather than the end, of a long but crucial political and academic process. 


\section{Section 4: Findings}

Section 4.1: Interviews

Despite the limited number of interviews and the presence of important differences between the participants in areas such as ethnicity, gender, class, proficiency of English, migration status, and qualifications, the migrant workers interviewed exhibited significant similarities in their experiences. With the exception of Mónica and Nefeli, all migrant workers described exploitative, physically demanding and sometimes even degrading working conditions in fields such as warehousing, hospitality and social care, confirming the findings of other scholars outlined above. Indicatively, Selu, a migrant worker from Spain who has worked in both London and Edinburgh over the course of 17 years in the UK, describes a trajectory which is widely generalizable:

[...] when I arrive I been doing by agency working in warehouses, later on I been working in restaurants, Spanish restaurants, later on the hospital porter, after that benefits, and when I finished the benefits, because I used the benefits to become administrator by the NVQ, then I start to work for the [large London university] and I been there 5 years'-Selu, Spanish male, early 40 s

Alternatively, Cellie arrived through an agency which had already found her a job for a fee; it involved cleaning caravans in a holiday park in Scotland, without a contract or guaranteed hours:

Interviewer: How long have you been working or looking for work in the UK?

Cellie: I just came through an agency, so from the beginning I had a job. I was with an agency in Spain, a Basque agency, so I paid like 300 euros?

Interviewer: You paid 300 euros to get here?

Cellie: Yeah, to get a job. So they were looking for a job for me [...] so when we arrived we didn't know the kind of jobs, it was like, girls for housekeeper, Spanish boys for waitering. Immediately 'you girls are going to be housekeepers and the guys going to be waitering'.

Interviewer: And, so were you, what type of contract did you have?

Cellie: Zero hours contract.

Interviewer: And that contract you had signed in Spain, right?

Cellie: I didn't sign anything.'- Cellie, Spanish female, early 30s

These excerpts are provided because Selu's experience is illustrative of the general trajectory of migrant workers and Cellie's is a manifestation of, once again, the same wider trends of precarity and the gendered nature of occupational distribution (Spanish 'boys' were waiters, Spanish 'girls' were cleaners). Other examples include those of Leila who also started working through agencies in jobs such as waitressing and kitchen portering, Marta who steadily worked in insecure, zero-hour contract service sector jobs, and Michelle who did a variety of gendered barista and caring jobs before eventually becoming a manager. The most extreme experience was recounted by Cellie concerning her time caring for a disabled middle class British woman in Edinburgh: 
'Cellie: I was covering a girl because she was ill. But then another girl left and.... But she never mentioned 'now you are hired', she was just like 'well if you want to stay, OK'.

Interviewer: Even afterwards, you never had a contract?

Cellie: No, I didn't sign anything as far as I can remember.

Interviewer: So it was basically just based on trust.

Cellie: Yes.

Interviewer: And that means that she could do with you whatever she wanted?

Cellie: Yes. I remember one of the times there was nothing to do. So she said 'I have an idea'. You know the toilet, if you see inside the toilet there is some orange marks from the water, sometimes the water just leaves a mark for a long time?

Interviewer: Yes.

Cellie: So 'you can maybe empty the toilet with a plastic, plastic glass, and then clean it with a toothbrush, I bought a product which is very nice'.

Interviewer: [silence]

Cellie: Yeah, and I said 'yes'.

Interviewer: [silence]

Cellie: Yeah I know, I never understood why I stayed so long there... [starts crying]'-Cellie, Spanish female, early 30 s

This experience reflects the previously analysed domains of precarity (through the lack of contract and resultant inability to exercise any control over her working life), migration (all of the workers caring for this woman were immigrants), class (Cellie's family, due to the effects of the Spanish economic crisis, depended on her remittances and this made it impossible for her to just leave the job), and gender (a large percentage of migrant women are employed as cleaners and domestic carers, with Cellie doing both at once- Recchi and Triandafyllidou 2010).

Interviewees expressed an inability to resist these conditions, mainly due to the precarious nature of the jobs:

'Interviewer: And in jobs like these were you expected to, let's say, just comply? So for example, you had a change of hours- was this arbitrary or was there, like, a consultation process?

Marta: No, it's basically 'comply or leave'. - Marta, Moldovan female, mid 20s

Experiencing precarity left participants feeling a loss of control over their lives and a complete submission to the demands of their employers. This is enforced by their being immigrants; for example, Selu states that 'in [large Edinburgh hotel] the power is by the locals and the people who are working like animals are the immigrants'. When describing the conditions of working in the production line of a biscuits factory, Cellie recalls feeling dehumanised: 


\section{'Interviewer: How did you feel when you were doing that job?}

Cellie: [....] I was feeling like, every time I pass this door and I enter this place, I am not a human for 8 hours. Like you don't, 'we are very democratic here', apparently, but we, in our job environment, in our work environment, we have to be under a structure, you know. You are here, and you have to obey. 8 hours, OK? Then you can go out and vote. But here, you are nothing. And you just

obey what I am saying, and you take your break when I am saying, and you can pee when I am saying'-Cellie, Spanish female, early 30 s

Varying degrees of xenophobic behaviours by British colleagues worsened participants' workplace experience. Such manifestations could either be relatively covert or particularly overt and violent:

'He took a knife and threaten the Spanish guy like 'what the fuck are you doing in my country, do the things the way I told you fucking immigrant'. With a knife. A guy who is completely drunk.'- Andre, Spanish male, early 30s

Importantly, the status of a being a migrant is not enough to foster solidarity. Cellie describes the exclusion she felt as a Spanish migrant working amongst a predominantly Polish female workforce:

'The other girls were all of them Polish. Absolutely all of them. When I arrived to the line, I remember it was an old woman and she said 'there is another Spanish girl there', like, 'you can go with her because we are not talk to you'. There was a Polish girl here, another girl here, another girl here, they were talking Polish all the time, no English [....] they basically only speaking in English when they were telling me I was doing wrong something'. - Cellie, Spanish female, early 30s

The persistence of such splits between workers in the same workplaces potentially has detrimental impacts on the fostering of the solidarity relationships that are a prerequisite of unionisation.

Despite a pretty consistent description of the negative conditions they experienced and are experiencing, only 4 out of the 9 migrant workers interviewed were unionised. This is significantly higher than the $16 \%$ of union density for migrants in the UK, but this sample is not representative since they were recruited from my own union; I wanted to find out what prompted them to join and how they felt as migrant workers in the union. All of the unionized migrants responded that they joined because they were already politicized and came across the union in a variety of events. For example:

Interviewer: But being already politicized played a big role in finding a trade union?

Mónica: Yeah, otherwise it would not have been visible enough in my everyday life for me to feel that it was relevant.'- Mónica, Colombian female, early 30 s

Alternatively, Nefeli said that one of the main reasons she did not join a union, even though she is politicized, is the bureaucratic and corrupt impression they left her with from her time in Greece. This suggests that the ideas that migrants carry with them from their countries of origin are as important as their experiences in the host country. 
Participants were aware of the structural constraints precarious labour poses on unionization. Michelle said that the jobs' temporariness made organising a union seem pointless. Furthermore, the physically demanding and unstable nature of precarious labour leaves little time or energy for such efforts (interview with Marta). Selu highlighted the fact that we were discussing migrant unionization in a context where even the British are overwhelmingly unorganised and thus unions are generally weakened.

Discussing behaviours which might distance migrant workers from unions, Mónica spoke of the cultural insensitivity of some unions towards migrants, especially when it comes to non- EU migrants who suffer from the additional anxieties of various kinds of tenuous migration statuses:

[....] precarious contracts for us also mean the threat of deportation and like the inability to settle down in a place because you don't know if you, because your staying here depends on having a job with a certain amount of hours, a certain salary, so like, in the way that... you know, I don't know if the unions really understand that.'- Mónica, Colombian female, early $30 \mathrm{~s}$

Insensitivity regarding the specific conditions of diverse migrant groups was also cited by Nefeli, a support worker in an organisation catering to BME immigrant women, as a significant barrier to their involvement:

'It is called cultural sensitivity [....] These are very, very important things to understand that if you have language barriers, if you have cultural barriers, if you have immigration issues or whatever that is, that you have faced in your life, these people- they don't always have the same starting point

[....] So understand that migrants are also a very diverse group with a lot of divisions in it, it's a different thing to speak to Latin Americans or Mediterraneans or to speak to a South African or to someone from an Arab country, see the dynamics in the Arab countries or Eastern Europe after communism... so it's very diverse'- Nefeli, Greek female, early 30 s

This lack of awareness (and, arguably, interest) regarding the specificities of migrant workers has resulted in Manuel claiming that mainstream unions 'have zero interest in migrant workers'.

According to Selu, the lack of access to unions is also accentuated by language difficulties: he claims that when he arrived in the UK, even if there was union in his workplaces, he wouldn't have been able to read their materials. However, he also said that 'the unions doesn't care about the immigrants' until they are seen as useful- then 'all the unions that are working with manual workers they want to have the Latin Americans because they are the only with the capacity to call for a demonstration and they are massive'. This resonates with Cappiali's (2017) study of the tokenistic approach that the Italian left employs towards migrants. Furthermore, Selu mentioned that in one of his workplaces the British union members were actively involved in perpetuating systems of ethnic privilege and hierarchy, and would therefore not be interested in organising with migrant workers.

While all of the aforementioned barriers to migrant worker organisation are important, what emerged from the interviews is that perhaps the most significant obstacle is the sheer absence of contact between migrants and unions, whether inside or outside the workplace. Indicatively, all of the unorganised participants claimed that, were a union present in their workplaces, they would have joined. However, none had ever been approached by a union. For example: 
'Interviewer: And so, why have you not joined a union even though you are in these precarious positions?

Leila: Because I have never heard about them. Like, because I have never heard about them in the UK, because I have participated in some of them in Spain, but here, because I have never heard about them, therefore I automatically realise that they not gonna be of any help to me, because they

weren't in any of the places that I been. I've never seen them, I've never seen any... I've never received any leaflet, any nothing from them saying 'look, this is us, if you need anything this is where you can find us', so yeah. Like, I haven't taken them any consideration because they haven't, like, they haven't succeed in the effort to reach people, so is just not an option for me.

Interviewer: $O K$, so, if there was a presence in your jobs of unions or some sort of contact, do you think that you would have joined?

\section{Leila: Of course!}

Leila: [....] I think that they have completely failed to protect and provide protection to the European workers and non-European workers, like, workers in general.

Interviewer: OK, and how does that make you feel about unions in general?

Leila: Well, as I said, like, you know, I have completely assumed that if I had a problem, I would never rely on them, I would try to find another way. For me, they don't exist at all.'- Leila, Spanish female, late 20 s

\section{Section 4.2: Auto-ethnography (observation of small Spanish Tapas Restaurant in West End of Glasgow)}

I worked as a kitchen porter from mid- July to mid- August 2017. I found the job by giving in a $\mathrm{CV}$ and was called immediately for an unpaid trial shift. I agreed to $7 f$ an hour cash-in-hand, below the minimum wage and illegal. When I asked for a contract, the manager's reply was 'be serious, no one gets a contract in this place'. There are usually 3 staff at the front of the shop (manager plus 2 waiters) and 3 staff at the back of the shop (chef, kitchen assistant, kitchen porter). When I left, the restaurant's demographics were: 1 male Portuguese manager, 1 Spanish-Italian waitress, 1 Scottish waitress, 1 Scottish chef, 1 female Spanish chef, 2 male Greek kitchen porters that interchange (including myself) and 1 female Romanian kitchen assistant. Sexism is rampant in the workplace, with the manager constantly touching the female staff and demanding displays of affection such as hugs and kisses and making vulgar comments behind their backs.

Work is physically demanding on all concerned except the manager, who sits down whenever he wants. For the rest of us there is always something to do and it usually involves standing up without a break. The kitchen porter position has a constant stream of plates, cutlery, pots, pans and containers to clean. I was only provided with gloves on the $3^{\text {rd }}$ week. Getting cut or burnt is unavoidable and the first aid kit was empty. There were 2 papers stuck on the wall in the store-room detailing some basic rights but the manager told me that they exist only for legal reasons and that they 'mean nothing'. There is a blatant disregard for even the limited labour rights that exist.

The most glaring characteristic of the workplace environment was the turnover and the precarity. People came and went at a tremendous pace. In my first 3 weeks a total of 4 people (more than half the staff) permanently left- 2 got fired and 2 (an Italian and a Spanish chef) both found a better job. The hours are unstable and impossible to predict: I worked 27 hours in my first week, 23 in the second, 35 in the third, and 14 in the fourth. The conditions in the restaurant are fully in line with Lucas and Mansfield's (2010) analysis of migrant labour in the hospitality sector. 
The business is trying to save money at all costs and cuts corners on absolutely everything. Indicatively, I was once told to rub lemon on out- of- date chicken to cover the rotting smell so that it could be cooked and sold. This mentality is coupled with an exaggerated pressure to 'perform', to keep clients as happy as possible and their waiting times at an extreme minimum. This results in the application of intense pressure by the manager towards the staff and creates a sustained climate of worker dissatisfaction. Perfectly conscious of the ease with which employees could desert the business given the flexibility of the working relations, the manager resorts to a 'carrot and stick' approach where he either issues aggressive threats or tries to appease the worker. In my case this has manifested either in threats to fire me or in compliments, promises of a gradual promotion and the issuing of extra money. Alternatively, the manager regularly takes workers to the side to complain about other workers not doing their job correctly and ruining it for everyone. This is a conscious tactic that aims at creating a united front with the worker against another worker.

The Tuesday of my fourth week, a particularly arduous and stressful workday, further enforces the above descriptions. Upon repeated occasions of disrespect and unrequired pressure by the manager I began visibly displaying my disaffection. The manager pulled me to the side, complained about the current chef and promised me that I would be trained to become a chef and 'get more money'. When I told him that I was not interested and that I am frustrated with his behaviour, he told me that he would pay me more for this shift because 'you know I look out for you'. At the end of the day he asked to speak to me again and said that I shouldn't be frustrated because 'this is the job' and told me that I have these concerns because I am a student and can therefore get a better job. 'If you really needed this job and you were really worried about keeping it you would just work'. This comment is illustrative of the entirety of these findings. I aggressively replied that if I really wanted this work I would try to create a union and change the conditions of the workplace. Upon hearing this he began blaming the Scottish chef's organisational capabilities and arguing that if it wasn't for him the place would be running perfectly. Finally, he stated that he wanted me to take over that position and went back inside the restaurant.

This day also provided me with my only opportunity to seriously discuss unionization. I was cleaning the kitchen with the Spanish chef and we began discussing our working conditions, both voicing displeasure. She was engaging in a combination of intense criticism of the management and of comparisons between the working conditions in this job and the Spanish labour market, arguing that 'at least this is better'. I ended up mentioning the need for a union and she responded that if there was one she would have joined it. Significantly, she voiced an uncertainty about whether foreigners and people without contracts can join. Both concerns are not valid; migrants can join unions, with or without a contract. However, they highlight both the absence of unions from such workplaces and their significant failures to raise awareness and reach workers.

Other than this conversation the opportunities to discuss unions were rare. Sometimes the word 'strike' was mentioned, but it was purely as a joke and the manner with which it was invoked highlights the perceived utter impossibility of ever actually holding one. Perhaps the biggest barrier to unions in that workplace was exactly how irrelevant and even ridiculous their presence seemed. Although everyone wanted an improvement in conditions, they were perceived as unchangeable. Instead, in a manner related to Alberti's (2014) research on the utilization of mobility, people invoked their temporariness. Phrases along the lines of 'I will not be working here for long' or 'I' $m$ already looking for another job' were very common. Furthermore, the volume of work and the constant pressure prevented opportunities for serious conversations. An additional obstacle were the irregular shifts which prevented the formation of genuine bonds between us. Without trust it is hard to discuss potentially dangerous topics such as unions. 


\section{Section 5: Discussion and Recommendations}

The interviews and the auto-ethnography have confirmed various previous scholars' findings that migrant workers are prone to be located in precarious, exploitative and symbolically stigmatised jobs. Within the context of a generalised assault on workers' rights (Moore 2011), migrant workers are more likely than the British-born to find themselves at the forefront of the precarious condition (Jørgensen 2016; Standing 2011). Furthermore, it was confirmed that migrant jobs are highly gendered, with migrant women experiencing the thrust of the generalised decrease in labour standards and being confined to hospitality or caring occupations. Finally, the lack of migrant unionization relative to the British population was also established. Both subjective and structural constraints are responsible for this. However, the most significant barrier to unionization was not sufficiently covered by the literature: unions were found to be entirely absent from the occupations and lives of immigrant workers. While more widely generalizable research is necessary to concretely substantiate this conclusion, I believe that the interviews, ethnography, and literature review nevertheless provide enough evidence to, at the very least, suggest a serious tendency of union absence from such workplaces.

Subjective impediments arise as almost inevitable products of the migrant condition and include temporariness, the migrants' dual frame of reference, lack of information or language difficulties, prejudiced attitudes within the migrant community, and previous political experience. While temporariness can be a structural product of institutionalised precarity, in its subjective sense it refers to the idea of mobility that migrants possess, to some extent liberating them from being tied to one specific job; this in turn makes it not seem worth the effort to organise to improve conditions (Alberti 2014; Cook et al 2011). The 'dual frame of reference' refers to the tendency to view an occupation in the UK favourably through comparing it to a worst labour market in one's home countrythis debilitates the quest to improve conditions, because one's conditions are already perceived as an improvement (Piore 1979). Such opinions were frequently voiced both by workers in my workplace and by my interview participants. Lack of information or language difficulties objectively hinder migrant participation, but they are gradually overcome as migrants settle in the UK (Anderson 2010). Prejudiced attitudes by other migrants were mentioned in Cellie and Leila's interviews and are also cited in McDowell (2008)- these divisions debilitate the formation of a wider migrant-worker identity, a prerequisite for the formation of political subjectivities based on solidarity (Alberti et al 2014). Finally, previous political experience emerged as perhaps the most crucial determinant of subsequent migrant worker unionization: every unionized immigrant interviewed had previous political experience in their country of origin, including myself.

Structural impediments concern the location of most migrants in precarious labour, the rise of xenophobic attitudes, the general decline of union activity, and the attitude of unions towards migrant workers. The interviews and the auto-ethnography corroborate the literature's findings that migrants are disproportionately located in jobs without unions. None of the migrants interviewed came from a unionised workplace. The lack of employment rights and the consequent pressure to 'comply or leave' (interview with Marta) make organising unions potentially dangerous for precarious workers (Anderson and Ruhs 2010). Xenophobic attitudes by members of the local, British working class exclude migrants from the collective life of the workplace and interrupt the creation of interethnic unionised collaborative structures and of the mentalities that are a prerequisite thereof (Castles 2000). Finally, the attitude of unions towards migrant workers was found to represent a significant barrier to their active, substantive incorporation, reflecting Cappiali's (2017) arguments that migrants are viewed tokenistically. To this end, Mónica spoke about how unions just 'assume that you know' intricacies such as those concerning UK strike laws and don't try to facilitate migrants' assimilation to the new conditions. Manuel, on the other hand, stated that the absence of unions from the forefront of migrant solidarity struggles reduces the trust with which migrant workers view them. Importantly, status considerations were not mentioned by any of the 2 non- EU migrants interviewed as a debilitating factor to their unionisation. This does not mean that migrant workers are not afraid that, 
by being fired for union activity, they will lose their Visa (Marino et al 2015). However, it does mean that residency status potentially is perhaps not the primary reason that migrants do not unionise, and has to be viewed in conjunction with the general lack of information supplied by unions to migrant workers and with their utter absence from migrants' lives.

While unions are generally weakened and absent from precarious occupations, the extent of unions' absence from migrants' lives seems to not be purely attributable to structural forces. It seems that this absence is, to some extent, a product of indifference at either local or national level. The overwhelming majority of the migrants interviewed had never been approached by a union. They did not have contact with unions inside or outside the workplace. The migrants who were unionised did so purely because they already had an acute political consciousness from their home countries. Selu joined the IWW after seeing them hold an action against university management, but that was in London which is a hotbed of migrant-led union activity, particularly active in the last few years (Lagnado 2015), and is not generalizable. Moreover, as will be further examined below, unions in London employ specific intersectional practices that resonate with the conditions of migrant workers. Mónica's union only contacts her through emails. Nobody else had ever seen a union in their workplace and nor had they been approached in other ways, whether in the street through leaflets or in their communities through events. These migrants have been through a variety of jobs in the UK and therefore, alongside the literature which also suggests the absence of unions from the migrants' workplaces, it is possible to conclude that the lack of contact between migrants and unions is generalizable. Despite this, all of the non-unionised migrants said that, were there a union in their workplace, they would have joined it. This is in line with Fine and Holgate's (2014: 134) findings, spanning the UK, Germany, USA, and France, that 'immigrant workers both need and want to join unions' [authors' italics].

Migrants therefore enter a context which is already defined by deepening precarity, xenophobia, and the weakening of unions. Placed in the most precarious jobs due to a combination structural processes, subjective tendencies, and the operation of ethnic, racial, gender stereotypes, their precarity is further entrenched by the almost total absence of unions in their lives. The primary concern of unions aiming at organising with migrant workers should therefore be to achieve a visibility and presence in migrant workers' lives and occupations. This can be achieved by: (1) physically going to workplaces that employ migrant workers and distributing union propaganda such as leaflets, translated in various languages, which will include information on how to access assistance regarding other, non-union related issues, such as benefits or migrant rights; (2) the fostering of relationships between unions and local community migrant organisations; and (3) holding public events in migrant communities that aim to raise awareness of unions and to build solidarity between unions and migrant communities. Once initial visibility and contact are achieved in a non-authoritarian, collaborative way which recognises migrant workers as political subjects rather than passive populations (Però and Solomos 2010), the added impediments arising from subjective and structural sources may begin to be addressed. But without unions establishing their presence in both workplaces and communities, any further progress is impossible.

Existing literature on migrant-focused union campaigns highlights the need for migrant-led strategies that are closely connected with migrant communities (Alberti et al 2014; Moore 2011; Lopez and Hall 2015). Alberti et al (2014) find that union campaigns are more successful where they engage migrants as migrants rather than as general members of the working class. Furthermore, various studies (such as Jayaraman 2005; Lopez and Hall 2015; Ness 2005) have found that bottom-up participatory structures are successful both in producing positive results and in directly empowering migrant workers, thereby ensuring sustainability.

Latin American union struggles in London provide a valuable example of migrant organising because these workers dealt with a considerable proportion of the difficulties that migrants in the UK face regarding precarity and organising against it. In Però's (2014) study of the Latin American Workers 
Association (LAWAS), an intersectional approach regarding ethnicity and class emerges as crucial to organising efforts, with LAWAS alternating between dealing with workplace issues and demanding general social recognition and rights. Significantly, the campaign emerged only after people had solved more immediate issues such as housing, immigration, and benefits concerns. Furthermore, it is also important to note that many organisers had extensive previous union experience in their home countries (Lagnado 2015). These workers were initially excluded or side-lined in mainstream unions, and, when finally beginning to collaborate with Unite, felt the tokenism described above (Lagnado 2015). In response, they proceeded to break from Unite and join the Industrial Workers of the World, a move that, thanks to the IWW's organising structure, allowed them more independence and room to struggle on the various intersections of their precarity (Lagnado 2015, Jayaraman and Ness 2005b). Translating Freirian participatory and educative methodologies to their own context (Freire, P. (1993 [1970], Jayaraman and Ness 2005b), they extensively relied on educational work in order to both organise workers and empower them (Lagnado 2015), understanding that sustainable victories are inseparable from developing autonomy. While LAWAS is no longer active, its members have gone on to organise and participate in a variety of initiatives. Recently, the autonomous migrant-led union Independent Workers of Great Britain held the biggest strike of outsourced workers in the education sector in the UK's history (IWGB 2018).

These approaches resonate with Virdee's (2000) writings on the unionization of racialized workers in the UK: following Miles (1982), he identifies racialized workers as a class 'fraction', experiencing similar but also different realities to the wider British white working class. These structural and subjective differences mean that racialized, 'othered' workers, including migrant workers, require the formation of their own autonomous structures within the wider trade union structure in order to secure adequate representation of their interests (Virdee 2000). Marino et al (2015: 10) thus write that labour unions must 'act as a civil society actor in favour of immigrants rather than as a strictly labour-related interest body'; as previously stated, the economic domain is inseparable from wider social forces, both actively structuring and influencing each other (Young 1990). The active incorporation of intersectional ideas by trade-unions is therefore a prerequisite to successful and empowering organising with migrant workers (Holgate 2005; Moore 2011).

\section{Section 6: Conclusion}

Combined with the literature, therefore, the findings suggest that most unions in the UK have been largely unsuccessful in mobilizing intersectional analyses to adequate approach, empower, and unionize migrant workers. While the limited scope of the research prohibits a definite conclusion at this stage, it is nevertheless possible to trace some important trends. The combination of structural and subjective impediments to migrant unionization seem to be less to blame for the relative lack of unionised migrants than the general absence of unions from migrants' lives, both inside and outside the workplace. Further research is necessary to account for this absence. Yet, based on the literature covered and the findings of the research, it is possible to conclude that the subjective and structural impediments to migrant worker unionisation are significantly exacerbated by unions' inability to: (1) be present in workplaces employing migrants; (2) build relationships with migrant communities; (3) mobilize intersectional analysis to approach populations whose oppressions are not only structured by class; and (4) provide existing unionised migrant workers with the autonomy required to address their specific issues. While exceptions to this do exist, the findings and literature suggest that the inexistence of unions in precarious, migrant-employing workplaces is a generalizable reality. Of course, more research is necessary to be able to provide recommendations with complete confidence; this would specifically involve interviews with a more representative sample of participants (especially non-EU migrant workers) and an examination of more sectors employing migrant workers. I am currently working on such a project. Nevertheless, this preliminary article should suffice for the development of some main parameters that need addressing. 
Before anything else, unions need to develop connections with migrant communities. A prerequisite for this is the relinquishing of strict economistic analytical frameworks and the espousal of intersectionality, enabling unions to engage migrant workers as migrants as well as workers. This involves unions mobilizing themselves on wider social issues such as benefits or migrant rights. Autonomous structures, led by migrant workers and targeting issues of relevance to their lives, are crucial for successful and sustainable campaigns. This in turn leads to the importance of autonomy and direct democracy. All in all, a substantial part of trade unions' 'traditional', hierarchical, classcentred remit must be overturned and replaced by intersectional and non-hierarchical organising methods in order for them to be able to organise with, support, and empower migrant workers.

\section{Bibliography}

Adler, L. H. et al (eds.) (2014) Mobilizing Against Inequality: Unions, Immigrant Workers, and the Crisis of Capitalism. New York: Cornell University Press

Alberti, G. (2014) Mobility strategies, 'mobility differentials' and 'transnational exit': the experiences of precarious migrants in London's hospitality jobs. Work, Employment and Society, 28 (6), pp. 865881

Alberti, G. et al (2014) Opportunity and Choice for Unions Organising Immigrant Workers: A Comparison across Countries and Industries. In: Adler, L.H. et al (eds.) (2014) Mobilizing Against Inequality: Unions, Immigrant Workers, and the Crisis of Capitalism. New York: Cornell University Press

Alberti, G. et al (2013) Organising migrants as workers or as migrant workers? Intersectionality, trade unions and precarious work. The International Journal of Human Resources Management, 24 (22), pp. $4132-3148$

Anderson, B. (2013) Us \& Them? The Dangerous Politics of Immigration Control. Oxford: Oxford University Press

Anderson, B. (2010) Migration, Immigration Controls and the Fashioning of Precarious Workers Work. Work, Employment and Society, 24 (2): 300-317.

Anderson, B. and Ruhs, M. (2010) Migrant Workers: Who Needs Them? A Framework for the Analysis of Staff Shortages, Immigration, and Public Policy. In: Ruhs, M. and Anderson, B. (eds.) (2010) Who Needs Migrant Workers? Labour Shortages, Immigration, and Public Policy. New York: Oxford University Press

Bauman, Z. (2004) Wasted Lives: Modernity and its Outcasts. Cambridge: Polity Press

Cappiali, T. (2017) "Whoever decides for you without you, s/he is against you!": immigrant activism and the role of the Left in political racialization. Ethnic and Racial Studies, 40 (6), pp. 969-987

Casas-Cortés, M. (2014) A Genealogy of Precarity: A Toolbox for Rearticulating Fragmented Social Realities in and out of the Workplace. Rethinking Marxism, 26(2), pp. 2016-226

Castles, S. (2000) Ethnicity and Globalization. London: Sage

Caviedes, A. (2010) The Sectoral Turn in Labour Migration Policy. In: Menz, G. and Caviedes, A. (eds.) (2010) Labour Migration in Europe. Basingstoke: Palgrave Macmillan

Connoly, H. et al (2014) Trade union renewal and the challenges of representation: Strategies towards migrant and ethnic minority workers in the Netherlands, Spain and the United Kingdom. European Journal of Industrial Relations, 20(1), pp. 5-20 
Cook, J. et al (2011) The Experiences of Accession 8 Migrants in England: Motivations, Work and Agency. International Migration, 49(2), pp. 54-79

Department for Business, Energy and Industrial Strategy (2017) Trade Union Membership 2016: Statistical Bulletin. [Online] Available:

https://www.gov.uk/government/uploads/system/uploads/attachment data/file/616966/tradeunion-membership-statistical-bulletin-2016-rev.pdf [Accessed 10 July 2017]

Federici, S. (2012) Revolution at Point Zero: Housework, Reproduction, and the Feminist Struggle. Oakland: PM Press

Freire, P. (1993 [1970]) Pedagogy of the Oppressed. London: Penguin Books

Gorodzeisky, A. and Richards, A. (2013). 'Trade unions and migrant workers inwestern Europe'. European Journal of Industrial Relations, 19 (3): 239-54

Holgate, J. (2005) Organizing migrant workers: a case study of working conditions and unionization in a London sandwich factory. Work, Employment and Society, 19(3), pp. 463-480

IWGB (2017) Hundreds to protest in support of striking outsourced workers at the University of London. Independent Workers Union of Great Britain. [Online]Available:

https://iwgb.org.uk/2018/04/24/hundreds-to-protest-in-support-of-striking-outsourced-workers-atthe-university-of-Iondon/ [Accessed 09/05/2018].

Jayaraman, S. (2005) La Alianza Para La Justicia: A Team Approach to Immigrant Worker Organizing. In: Jayaraman, S. and Ness, I. (eds.) (2005) The New Urban Immigrant Workforce: Innovative Models for Labor Organising. New York: M.E. Sharpe

Jayaraman, S. and Ness, I. (eds.) (2005) The New Urban Immigrant Workforce: Innovative Models for Labor Organising. New York: M.E. Sharpe

Jørgensen, M. B. (2016) Precariat - What it Is and Isn't - Towards an Understanding of What it Does. Critical Sociology, 42(7-8), pp.959-974

Keenan, D. (2015) Is Another Unionism Possible? Solidarity Unionism in the Industrial Workers of the World in the U.S. and Canada. Working USA: The Journal of Labor and Society, 18, pp. 211-229

Kranendonk, M. and de Beer, P. (2016) What Explains the Union Membership Gap between Migrants and Natives? British Journal of Industrial Relations, 54(4), pp. 846-869

Lagnado, J. (2015) Towards a history of the Latin American Workers Association 2002-12. In: Choudry, A. and Hlatshwayo, M. (eds.) (2015) Just Work? Migrant Workers Struggles Today. London: Pluto Press

Lopez, A. and Hall, T. (2015) Organising migrant workers: the living wage campaign at the University of East London. Industrial Relations Journal, 46(3), pp. 208-221

Lucas, R. and Mansfield, S. (2010) The Use of Migrant Labour in the Hospitality Sector: Current and Future Implications. In: Ruhs, M. and Anderson, B. (eds.) (2010) Who Needs Migrant Workers? Labour Shortages, Immigration, and Public Policy. New York: Oxford University Press

MacKenzie, R. and Forde, C. (2009) The rhetoric of the 'good worker' versus the realities of employers' use and the experiences of migrant workers. Work, Employment and Society, 23(1): 142159

Majumdar, N. (2017) Silencing the Subaltern. [Online] Catalyst: A Journal of Theory and Strategy. Available: http://catalyst-journal.com/vol1/no1/silencing-subaltern-nivedita-majumdar.html [Accessed 30 June 2017] 
Marino et al (2015). 'Trade unions, immigration and immigrants in Europe revisited: unions' attitudes and actions under new conditions'. Comparative Migration Studies, 3 (1), 1-16

Martínez Lucio, M. and Perret, R. (2009) Meanings and dilemmas in community unionism: trade union community initiatives and black and minority ethnic groups in the UK. Work, Employment and Society, 23(4), pp. 693-710

McCollum, D. and Findlay, A. (2015) 'Flexible' workers for 'flexible' jobs? The labour market function of A8 migrant labour in the UK. Work, Employment and Society, 29(3), pp. 427-443

McDowell, L. (2008) Thinking through work: complex inequalities, constructions of difference and trans-national migrants. Progress in Human Geography, 32(4), pp. 491-507

McKay, S. and Markova, E. (2010) The operation and management of agency workers in conditions of vulnerability. Industrial Relations Journal, 41(5): 446-460

Meardi, G. et al (2012) Constructing Uncertainty: Unions and Migrant Labour in Construction in Spain and the UK. Journal of Industrial Relations, 54 (1), pp. 5-21

Menz, G. and Caviedes, A. (2010) Introduction: Patterns, Trends, and (Ir)Regularities in the Politics and Economics of Labour Migration in Europe. In: Menz, G. and Caviedes, A. (eds.) (2010) Labour Migration in Europe. Basingstoke: Palgrave Macmillan

Miles, R. (1982) Racism and Migrant Labour. London: Routledge

Moore, S. (2011) New Trade Union Activism: Class Consciousness or Social Identity? Basingstoke: Palgrave Macmillan

Mujamdar (2017) Silencing the Subaltern. Catalyst, 1 (1). [Online] Available: https://catalystjournal.com/vol1/no1/silencing-the-subaltern. [Accessed 13 August 2017]

Ness, I. (2005) Community Labor Alliances: Organising Greengrocery Workers in New York City. In: Jayaraman, S. and Ness, I. (eds.) (2005) The New Urban Immigrant Workforce: Innovative Models for Labor Organising. New York: M.E. Sharpe

Office for National Statistics (2017) International immigration and the labour market, UK: 2016.

[Online] Office for National Statistics. Available:

https://www.ons.gov.uk/peoplepopulationandcommunity/populationandmigration/internationalmi gration/articles/migrationandthelabourmarketuk/2016. [Accessed 10 July 2017]

Osterweil, M. and Chesters, G. (2007) Global Uprisings and the Politics of the Artisan. In: S. Shukaitis and Graeber, D. (eds.) (2007) Constituent Imagination: Militant Investigations, Collective Theorization. Edinburgh: AK Press

Però, D. (2014) Class Politics and Migrants: Collective Action among New Migrant Workers in Britain. Sociology, 48 (6), pp. 1156-1172

Però, D. and Solomos, J. (2010) Migrant politics and mobilization: Exclusion, engagements, incorporation. Ethnic and Racial Studies, 33(1): 1-18.

Piore, M.J. (1979) Birds of Passage: Migrant labor and industrial societies. New York: Cambridge University Press

Piper, N. (2010) Temporary economic migration and rights activism: an organizational perspective. Ethnic and Racial Studies, 33(1), pp. 108-125 
Recchi, E. and Triandafyllidou, A. (2010) Crossing Over, Heading West and South: Mobility, Citizenship, and Employment in the Enlarged Europe. In: Menz, G. and Caviedes, A. (eds.) (2010) Labour Migration in Europe. Basingstoke: Palgrave Macmillan

Sayad, A. (2004) The Suffering of the Immigrant. Cambridge: Polity Press

Spivak, G. C. (1988) Can the Subaltern Speak? [Online] Available:

http://abahlali.org/files/Can the subaltern speak.pdf [Accessed 10 July 2017]

Sporton, D. (2013) 'They Control My Life': the Role of Local Recruitment Agencies in East European Migration to the UK. Population, Space and Place, 19, pp. 443-458

Standing, G. (2011) The Precariat: The New Dangerous Class. London: Bloomsbury

Tapia, M. (2014) United Kingdom: Dialectic Approaches to Organizing Immigrant Workers, Postwar to 2012. In: Adler et al (eds.) (2014) Mobilizing Against Inequality: Unions, Immigrant Workers, and the Crisis of Capitalism. New York: Cornell University Press

Virdee, S. and Grint, K. (1994) Black Self-Organisation in Trade Unions. The Sociological Review, 42(2), pp. 202-226

Woodcock, J. (2014) Precarious workers in London: New forms of organisation and the city. City, 18 (6), pp. 776-788

Wrench, J, and Solomos, J. (1993) The Politics and Processes of Racial Discrimination in Britain. In: Wrench, J. and Solomos, J. (eds.) (1993) Racism and Migration in Western Europe. Oxford: Berg

Wrench, J. (2004) Trade union responses to immigrants and ethnic inequality in Denmark and the UK: The context of consensus and conflict. European Journal of Industrial Relations, 10(1): 7-30

Yilmaz, F. (2012) Right-wing hegemony and immigration: How the populist far-right achieved hegemony through the immigration debate in Europe. Current Sociology, 60(3), pp.368-381

Young, I.M. (1990) Justice and the Politics of Difference. New Jersey: Princeton University Press 
